\title{
Schutz vor UV-Strahlung lässt sich offenbar schlucken
}

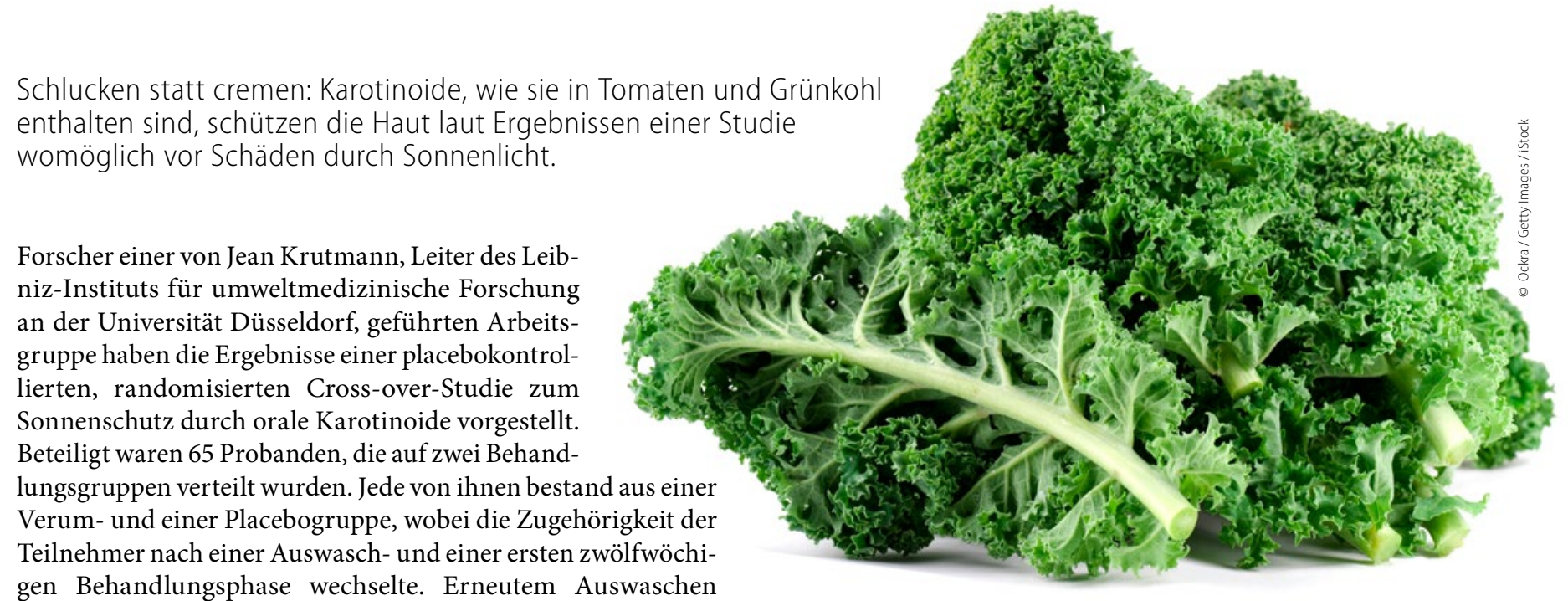

gen Behandlungsphase wechselte. Erneutem Auswaschen schloss sich im Cross-over eine erneute zwölfwöchige Therapiephase an.

Als Verum getestet wurde zum einen ein lykopinreicher Nährstoffkomplex aus Tomaten in Kapselform. Die Kapseln enthielten $5 \mathrm{mg}$ Lykopin, dazu weitere Phytonährstoffe wie Phytoen, Phytofluen, Tokopherole und Phytosterole. Die Dosis betrug zweimal täglich zwei Kapseln. Beim zweiten Verum handelte es sich um Kapseln mit 10 mg Lutein, von denen zweimal täglich eine einzunehmen war. In den verwendeten Placebokapseln befand sich Sojaöl.

\section{Gene in Hautgewebe untersucht}

Jeweils zu Beginn und am Ende einer Therapiephase wurde die Haut der Probanden im Gesäßbereich mit UV-A-/UV-B- und UV-A1-Licht bestrahlt. 24 Stunden später entnahmen die Wissenschaftler Hautproben aus unbestrahlter und bestrahlter Haut und untersuchten sie auf Genveränderungen, die für solarstrahlungsbedingte Hautschäden typisch sind.

In der Analyse zeigte sich, dass der Tomaten-Nährstoff-Komplex die UV-A-/UV-B- und UV-A1-bedingte Hochregulation

von mRNA der Hämoxygenase 1, des interzellulären Adhäsionsmoleküls 1 und der Matrix-Metallopeptidase 1 signifikant hemmt. Auch Lutein bot diesbezüglich einen bedeutsamen Schutz, aber nur, wenn es in der ersten Therapiephase gegeben wurde. In der zweiten Phase fiel der Effekt verglichen mit dem Tomaten-Nährstoff-Komplex signifikant geringer aus. Krutmann und Kollegen vermuten, dass die Zeit nicht ausgereicht hatte, um vergleichbare Wirkspiegel wie in der ersten Phase zu erreichen, und das Lutein sich andernorts angereichert hat.

„Unter der Annahme, dass die genannten Gene Indikatoren für oxidativen Stress, Photodermatosen und lichtbedingte Hautalterung sind, könnten unsere Resultate Hinweise darauf geben, dass der Tomaten-Nährstoff-Komplex und Lutein vor Hautschäden durch Sonneneinstrahlung schützen“, schreiben die Forscher in ihrem Fazit. Kapseln zu schlucken ist dafür ihren Angaben nach nicht nötig. Denn Tagesdosen von $20 \mathrm{mg}$ Lutein und $20 \mathrm{mg}$ Lykopin nimmt bereits zu sich, wer $130 \mathrm{~g}$ zerkleinerten Grünkohl und $242 \mathrm{~g}$ Tomatensaft konsumiert.

Dr. Robert Bublak

Literatur

Grether-Beck S et al. Br J Dermatol 2017; doi:10.1111/bjd.15080

\section{Weitere Infos auf SpringerMedizin.de}

Finden Sie weitere Artikel auf unserer Themenseite „Maligne Tumoren der Haut“. Lesen Sie online zum Beispiel

- "Neues zur Früherkennung und Screening des Melanoms" oder

- "Melanom: Männer haben schlechtere Prognose als Frauen"

Einfach im Internet unter SpringerMedizin.de "Maligne Tumoren der Haut"

als Suchbegriff eingeben und die Themenseite auswählen. 